1 Ordas et al.: flowering time and corn borer damage

2 Journal of Economic Entomology: Field and Forage Crops

3

4

5

6

7

8

9

10

11

12

$13{ }^{1}$ Misión Biológica de Galicia, CSIC, P.O. box 28, 36080 Pontevedra, Spain.

14

15

16

\section{Relationship between Time to Flowering and Stalk and Ear Damage by Second}

\section{Generation Corn Borers}

B. Ordás ${ }^{1}$, A. Álvarez ${ }^{2}$, P. Revilla ${ }^{1}$, A. Butrón ${ }^{1}$, R.A. Malvar ${ }^{1}$

$4 \quad 2$ Estación Experimental de Aula Dei, CSIC, Av. Montañana 1005, 50059 Zaragoza, Spain
B. Ordas

MBG, CSIC, P.O. box 28,

36080 Pontevedra, Spain

Phone: +34986854800

Fax: +34986841362

E-mail: bordas@mbg.csic.es 
17 ABSTRACT In the Mediterranean area, the main corn borer species are Sesamia nonagrioides Lefebvre (Mediterranean corn borer, MCB) and Ostrinia nubilalis Hübner

19 (European corn borer, ECB). In the overall context of integrated pest control, it is possible to reduce the effect of a pest without having a negative effect on the environment by varying the sowing date. Benefits are possible if the most susceptible stages of the crop no longer coincide with the peak of the pest. We used different cycles of selection $(0,6,8,10$, and 12$)$ of two populations (Purdue A and Purdue B) of maize selected for early flowering to get a more precise estimation of the relationship between maturity of plant tissues and corn borer damage. We found a relationship between the damage produced by corn borers and the number of days from flowering to infestation. We conclude that, after flowering, a later stage of plant development at the moment of the infestation by corn borers reduces the damage caused by the larvae. Based on our results, we recommend to plant as early as possible so the tissues would be as mature as possible at the moment of insect attack.

development, maize

\section{Abbreviations}


Corn borers are the main pests of maize, Zea mays L., in temperate areas. In Spain and other

Mediterranean countries, the main corn borer species are Sesamia nonagrioides Lefebvre

(Mediterranean corn borer, MCB) and Ostrinia nubilalis Hübner (European corn borer,

ECB). Two generations per year are common in the Mediterranean area for MCB and ECB.

The peak of flight for the first generation occurs usually in May, while the peak of flight for the second generation occurs usually during August and the beginning of September (Velasco et al., 2007). The damage produced by the first generation is generally low and affects the plants in juvenile stage, but the damage caused by the second generation can be high and affects the plants at flowering or at later stages of development (Velasco et al., 2007). This article will focus on the second generation.

In the overall context of integrated pest control, it is possible to reduce the effect of a pest without having a negative effect on the environment by varying the sowing date. Furthermore, the variation of the sowing date is one of the cheapest and easiest methods to apply. Benefits are possible if the most susceptible stages of the crop no longer coincide with the peak of the pest. Genotypes with a fast development, that is, early flowering genotypes, or genotypes that are planted earlier, will be in later stages of development at the moment of borer infestation. Several experiments have compared the damage on early vs. late genotypes, but contradictory results have been obtained. Thus, some authors have found a negative correlation between days to flowering and stalk tunneling in U.S.A. (Jarvis and Guthrie, 1980; Russell et al., 1974), Canada (Hudon and Chiang, 1991), and Germany (Schulz et al., 1997). The same relationship was found for ear damage in U.S.A. (Carlson and Andrew, 1976; Grier and Davis, 1980). However, other authors have not found a significant relationship between days to flowering and stalk damage by corn borers in U.S.A. (Khalifa and Drolsom, 1988) and Germany (Melchinger et al., 1998) or have found a positive relationship between days to flowering and ear damage in Spain (Malvar et al., 2002; Velasco 
et al., 2004a). In these experiments, different genotypes varying for days to flowering were compared, but the effects of genetic background and stage of development were confounded. It is possible that a sample of germplasm with a determined precocity will be more resistant for other genetic characteristics, independently of the stage of development at the moment of infestation. The study of the influence of the stage of development at the moment of infestation on the damage caused by borers can be better done by using the same genotype. Thus, it was found that ear damage and yield reduction due to corn borers are higher when plants are sowed late in the season in U.S.A. (Bode and Calvin, 1990; Patch et al., 1942) and Spain (Malvar et al., 2002; Velasco et al., 2004b). Similarly, Patch et al. (1942) have found that yield was greatest reduced when plots were infested earlier. Therefore, it seems that infestation at early stages of plant development produces higher damage than infestation at later stages. However, larvae infested at different times or plants planted at different dates are not exposed to the same environmental conditions and therefore, environmental effects could bias the comparisons between different plantings or infestation dates. More precise cycles $(0,6,8,10$, and 12$)$ of selection for early flowering in PA and PB. 
The cycles $0,6,8,10$, and 12 of PA and PB were random mated (PAC0-S0, PAC6-S0, etc), self-pollinated (PAC0-S1, PAC6-S1, etc), and crossed to the inbred EP28 (PAC0×EP28, PAC6×EP28, etc) in 2004. The cycles per se, self-pollinated, and crossed to EP28 were evaluated at Pontevedra (42 $\left.30^{\prime} \mathrm{N}, 8^{\circ} 46^{\prime} \mathrm{W}\right)$ and Zaragoza ( $\left.41^{\circ} 44^{\prime} \mathrm{N}, 0^{\circ} 47^{\prime} \mathrm{W}\right)$ at two sowing dates in 2005. Pontevedra is a coastal location in northwestern Spain at the sea level, whereas Zaragoza is inland and located in northeastern Spain at $250 \mathrm{~m}$ above sea level. Within each combination of location and sowing date, the populations with different inbreeding levels (S0, S1, and testcrosses) were evaluated in three different experiments located in adjacent fields.

No artificial infestation was made in experiment 1 , while plants were infested with one egg mass of MCB (50 eggs, approximately) in experiment 2 and with two egg masses of ECB (50 eggs, approximately) in experiment 3. MCB eggs were obtained following Eizaguirre’s method (Eizaguirre and Albajes, 1992), while ECB eggs were supplied by the Centre de Recherces de Poitou-Charentes (Institute National de la Recherche Agronomique, France). Infestations were made placing the eggs between the shank of the main ear and the 105 stalk.

The experimental design was a randomized complete block design with six replications in the experiments with natural infestation and three replications in the experiments with artificial infestation. Each experimental plot consisted of two rows with 9 plants per row. Rows were $0.80 \mathrm{~m}$ apart and hills in the row were spaced $0.21 \mathrm{~m}$ apart, obtaining a density of approximately 60,000 plants per hectare. Ten competitive plants per 111 plot were artificially infested. 

15th, while in Zaragoza is slightly earlier. In Pontevedra, the peaks of flight of MCB second generation adults occur around August 20th (Velasco et al., 2007), while in Zaragoza the peaks occur slightly earlier (unpublished data). The peaks of flight of ECB second generation adults occur earlier than the peaks of flight of MCB second generation adults (Velasco et al., 2007). The sowing dates in our experiments covered the appropriate period for maize sowing at each location: May 18 and June 7 in Pontevedra, and May 3 and June 10 in Zaragoza. For both pests the artificially infestation dates were chosen when the highest natural infestation was expected. Thus, for MCB the infestation dates were August 23rd and 25th for the early and late sowing dates, respectively, in Pontevedra, and August 17th and 18th for the early and late dates, respectively, in Zaragoza. For ECB, the infestation dates were August 12th for both sowing dates in Pontevedra, and July 28th and August 10th for the early and the late dates, respectively, in Zaragoza. For each combination of location, borer specie, and sowing date all genotypes were infested at the same day.

For each plot, days to flowering was recorded as the number of days from sowing to $50 \%$ of the plants showing silks. For each plot, the number of days from flowering to infestation was calculated in the experiments with artificial infestation. The number of days from flowering to infestation is a measure of the maturity of the plant tissues at the moment of infestation: more days from flowering to infestation indicates more maturity of the tissues at the moment of infestation. In the experiment with natural infestation the days from flowering to infestation could not be calculated because the moment of the infestation was unknown. In this experiment, a larger value of days to flowering indicates that the tissues were less mature at the moment of infestation. The ears were harvested in November, after all plants had reached physiological maturity. In the experiments artificially infested with corn borers, the main ears of the infested plants were harvested. The stems were dissected 
lengthwise, and the length of tunnels made by borers was measured. In the experiments under natural infestation 10 plants were chosen at random, their ears were harvested and their stalks were dissected. On the latter, the length of the tunnels caused by borers was measured. In addition to tunnel length $(\mathrm{cm})$, data recorded on the collected plants of each plot were: kernel, husk, and shank damage, and number of ECB and MCB larvae per plant. Kernel, husk, and shank damage were rated on a 9 point subjective scale as follows: 1 for more than $90 \%$ damage, 2 for 81 to $90 \%$ damage, 3 for 71 to $80 \%$ damage, 4 for 61 to $70 \%$ damage, 7 for 21 to $30 \%$ damage, 8 for 1 to $20 \%$ damage, and 9 for no damage.

To study the relationship between plant developmental stage at the moment of infestation and damage the simple linear regression coefficients of tunnel length, kernel, husk, and shank damage, and number of ECB and MCB larvae per plant on number of days from flowering to infestation were calculated in the experiments with artificial infestation. The same regression coefficients were calculated in the experiment with natural infestation, but instead of the number of days from flowering to infestation, the days to flowering was used. To deepen the understanding of genetic and environmental factors that interfere in the relationship between damage and plant developmental stage, analyses of covariance were carried out. The following sources of variation: locations, sowing dates, blocks, populations (Purdue A or Purdue B), and level of inbreeding (S0, S1, or crossed to EP28) and their interactions were included in the covariance model. The analyses were made independently for tunnel length, and for kernel, husk and shank damages. Covariance analyses with the same model, but with number of MCB and number of ECB larvae as the covariate, were also carried out. Covariance analyses of damage on number of days from flowering to infestation were carried out for individual locations, sowing dates, populations, and levels of inbreeding. In all cases, independent analyses were carried out for the experiments with natural, MCB, 
161 and ECB infestations. The analyses were performed with the GLM procedure of SAS (SAS

162 Institute, 2008).

163 
One way to study the relationship between flowering time and damage by an insect pest is planting the same genotype at different dates. This way, if we infest the plants on the same day, they will be in a different stage of development because they have suffered different environmental influences depending on the time of planting and it will be difficult to determine what part of the variation can be attributed to flowering time and what part to the vegetative stage of the plants. Infesting on different dates will not solve the problem because in this case are the insects who will suffer different environmental influences. One way to overcome this problem is planting on the same date genotypes that differ in their flowering times, but then the problem is to be able to distinguish which part of the damage is due to the date of flowering and which part is due to genotypic differences. The ideal situation would be to use genotypes that have the same genetic background and differ only in time of flowering; this would allow sowing all the individuals on the same day avoiding then the problems pointed out above. The populations used in this study are then very appropriate for this kind of study.

The simple regression coefficient of tunnel length on days to flowering was positive in the experiment with natural infestation (Table 1). The positive regression coefficient indicates that later flowering genotypes tend to have higher tunnel length, that is, suffer more damage by borers. Contrary to tunnel length, a lower value for kernel, husk or shank damage (due to the scale we used) indicates more damage, and a negative regression coefficient indicates that genotypes with later flowering tend to have more damage. In congruence with results obtained for tunnel length, we have found negative regression coefficients of kernel damage on days to flowering in the experiment with natural infestation. For tunnel length and kernel damage, the simple regressions of tunnel length and kernel damage on number of days 
from flowering to infestation were significant in the experiments with artificial infestation.

The genotypes in which more days had elapsed from flowering to the moment of infestation, that is, the genotypes with the tissues more mature at the moment of infestation tended to have shorter tunnel length and less kernel damage (Table 1). These results are in agreement with the results from the natural infested experiment because the number of days spent from planting to flowering is related to the maturity of the tissues at the moment of infestation. The early flowering genotypes, due of their fast rate of development, are attacked by corn borers at later stages of development.

In the experiments with natural infestation and with MCB infestation, the overall regression coefficients calculated including all factors in the covariance model (Tables 2, 3) confirm the relationship between the maturity of the tissues at the moment of infestation and both tunnel length and kernel damage found in the simple regression analysis. Most of the individual regression coefficients of tunnel length and kernel damage on number of days from flowering to infestation were significant in the experiment with MCB infestation. In the experiment with ECB, the overall and most of the individual regression coefficients of tunnel length and kernel damage on number of days from flowering to infestation were not significant, albeit most coefficients had the same sign than the coefficients in the MCB experiment (Table 4). This suggests that the effect between maturity of tissues and damage is weak in the case of ECB. Although the maize resistance to damage on kernels and stalks are not genetically associated (Malvar et al., 1996), both, according to our results, are related in a similar way with the number of days from flowering to infestation. According to the simple regression analysis and the covariance analysis, and contrary to tunnel length and kernel damage, husk and shank damage did not show a consistent relationship with number of days

212 from flowering to infestation across the experiments and seems to be not related with the 213 maturity of the tissues. 
The smaller amount of damage showed by the early flowering genotypes could be explained by an adverse effect of older plant tissues in the survival and/or growth of the larvae. In the simple regression analysis, we found a significant regression coefficient of number of MCB larvae on both days to flowering and days from flowering to infestation in the experiments with natural infestation and MCB infestation, and a significant coefficient of number of ECB larvae on days from flowering to infestation in the experiment with ECB infestation (Table 1). These results were confirmed for the results of the analysis of covariance for MCB, but not for ECB, and suggest a possible effect of tissue maturity on the survival of corn borer larvae, particularly MCB.

Therefore, the early flowering genotypes which were attacked by corn borers at later stages because of their fast rate of development had less damage both in the stalk and in the ear. These data are in agreement with some experiments that found lower ear damage or lower yield reduction in early plantings and later infested plots (Bode and Calvin, 1990; wall components, particularly lignin content, increases with the progressive maturity of the tissues (Morrison et al., 1998), plants are expected to have a higher concentration of cell wall components at later stages of development. Elevated concentration of cell wall components, which are mostly indigestible, may increase the bulk density of the diet to the point that insects are unable to ingest sufficient quantities of nutrients and water (Bernays, 1986). In addition, lignified cell walls may also produce tougher tissues that are resistant to the tearing action of mandibles (Raupp, 1985; Swain, 1979). Bergvinson et al. (1995) found that ECB larvae consume immature tissue at a higher rate than more mature tissue and that consumption rate was negatively correlated to leaf toughness. The effect of the tissue maturity on the larvae is expected to be highest at the first stages of larval development 
because the neonate mandibles may be less efficient to bite tougher, mature tissue

239 (Bergvinson et al., 1995).

In the three experiments, the regression coefficient of kernel damage was significant

in the early sowing, but not in the late sowing (Tables 2, 3, and 4). In addition, in the

experiment infested with ECB larvae the regression coefficient of tunnel length was significant in the early sowing, but not in the late sowing. In the early sowing the infestation with ECB and MCB was made after flowering for all genotypes (from 1 day to 35 days after flowering); however, in the late sowing the infestation with MCB, and particularly with ECB, was made before flowering for most of the genotypes. Lignification of the tissues occurs mainly from flowering to 30 days after flowering and, therefore, the genotypes in the early sowing had probably different levels of lignification at the time of infestation: from a low level in the genotypes that were near the flowering at the moment of infestation to a high level in the genotypes that were 30 days past flowering or more at the moment of infestation. Therefore, in the early sowing the different level of lignification, likely associated to the earliness of the genotypes, could explain at least partially the differences in damage between genotypes. On the opposite, the level of lignification of most genotypes was probably similar in the late sowing because most plants had not reached flowering yet. This could explain the lack of relationship between maturity and damage in the late sowing of some experiments. consistent across individual factors, but the magnitude varied between factors. Thus, in the experiment with artificial infestation with $\mathrm{MCB}$, the regression coefficient of tunnel length on days from flowering to infestation was significant in Pontevedra, but not in Zaragoza. In Zaragoza, MCB is poorly adapted and, for that reason, the establishment of the larvae in the plants is worse and this fact might mask the differences in resistance between genotypes. On the contrary, in the experiment with artificial infestation with ECB, the regression coefficient 
263 of kernel damage on days from flowering to infestation was significant in Zaragoza, but not

264 in Pontevedra where the ECB larvae have a poorer adaptation. Also, the magnitude of the

265 regression coefficients varied between populations; thus, the regression coefficient of kernel

266 damage was higher in Purdue A in the three experiments, while the regression coefficient of

267 tunnel length was higher in the Purdue B population in the experiment with MCB infestation.

268 As conclusion, after flowering a later stage of plant development at the moment of

269 corn borer infestation reduces the damage caused by the larvae both in stems and ears, and

270 the magnitude of this effect depends on the location, population, level of inbreeding, and

271 insect species. From our results we can deduct that it is worthwhile to plant as early as

272 possible so the tissues are as mature as possible at the moment of the attack of the insects. 
275

276

This research was supported by the National Plan for Research and Development of

277 Spain (Project Cod. AGL2006-13140). B. Ordas acknowledge a contract from the Xunta de 278 Galicia (Isidro Parga Pondal program). 
Bergvinson, D. J., R. I. Hamilton, and J. T. Arnason. 1995. Leaf profile of maize resistance factors to European Corn borer, Ostrinia nubilalis. J. Chem. Ecol. 21, 343-354.

Bernays, E. A. 1986. Diet-induced head allometry among foliage-chewing insects and its importance for graminivores. Science 231, 495-497.

Bode, W. M., and D. D. Calvin. 1990. Yield-loss relationships and economic injury levels for European corn borer (Lepidoptera: Pyralidae) populations infesting Pennsylvania field corn. J. Econ. Entomol. 83, 1595-1603.

Khalifa, I., and N. Drolsom. 1988. Combining ability for European corn borer resistance and three agronomic traits in maize. Maydica 33, 247-259. 
Malvar, R. A., A. Butron, M. E. Cartea, and A. Ordas. 1996. Ear resistance to pink stem borer in maize inbred lines. In: XVIIth Conference of genetics, biotechnology and breeding of maize and sorghum, Thesaaloniki, Greece, p. 96.

Malvar, R. A., P. Revilla, P. Velasco, M. E. Cartea, and A. Ordas. 2002. Insect damage to sweet corn hybrids in the south Atlantic European coast. J. Amer. Hort. Sci. 127, 693696.

Melchinger, A. E., R. Kreps, R. Späth, D. Klein, and B. Schulz. 1998. Evaluation of earlymaturing European maize inbreds for resistance to the European corn borer. Euphytica 99, 115-125.

Morrison, T. A., H. G. Jung, D. R. Buxton, and R. D. Hatfield. 1998. Cell-wall composition of maize internodes of varying maturity. Crop Sci. 38, 455-460.

Ordas, A., I. Santiago, R. A. Malvar, and M. I. Vales. 1996., Six cycles of selection for adaptation in two exotic populations of maize. Euphytica 92, 241-247.

Patch, L. H., G. W. Still, M. Schlosberg, and G. T. Bottger. 1942. Factors determining the reduction of yield of field corn by Ostrinia nubilalis. J. Agric. Res. 65, 534-539.

Raupp, M. J. 1985. Effects of leaf toughness on mandibular wear of leaf beetle, Plagiodera versicolora. Ecol. Entomol. 10, 73-79.

Russell, W. A., W. D. Guthrie, and R. L. Grindeland. 1974. Breeding for resistance in maize to first and second broods of the European corn borer. Crop Sci. 14, 725-727.

SAS Institute. 2008. The SAS system for Windows. Release 9.2. SAS Institute, Cary, NC.

Schulz, B., R. Kreps, D. Klein, R. K. Gumber, and A. E. Melchinger. 1997. Genetic variation among European maize inbreds for resistance to the European corn borer and relation to agronomic traits. Plant Breed. 116, 415-422. 
Swain, T. 1979. Tannins and lignins, pp. 657-682. In G. A. Rosenthal and D. H. Jazen (eds.), Herbivores: their interactions with secondary plant metabolites. Academic Press, New York.

Velasco, P., P. Revilla, M. E. Cartea, A. Ordas, and R. A. Malvar. 2004a. Resistance of early maturing sweet corn varieties to damage caused by Sesamia nonagrioides (Lepidoptera: Noctuidae). J. Econ. Entomol. 97, 1432-1437.

Velasco, P., P. Revilla, L. Monetti, A. Butron, A Ordas, and R. A. Malvar. 2007. Corn borers (Lepidoptera: Noctuidae; Crambidae) in Northwestern Spain: population dynamics and distribution. Maydica 52, 195-203. analysis of the damage caused by Sesamia nonagrioides (Lepidoptera: Noctuidae) and

338 Ostrinia nubilalis (Lepidoptera: Crambidae) in sweet corn ears. J. Econ. Entomol. 97, 120339 126. 
Table 1. Means of several traits and simple linear regression coefficients of tunnel length, kernel damage, husks damage and shank

341 damage on number of days from flowering to infestation.

\begin{tabular}{|c|c|c|c|c|c|c|c|}
\hline Cycle & $\begin{array}{l}\text { Days from } \\
\text { flowering to } \\
\text { infestation } \\
\text { (flif) }\end{array}$ & $\begin{array}{l}\text { Tunnel length } \\
\text { (tl) }\end{array}$ & $\begin{array}{l}\text { Kernel damage } \\
\text { (kd) }\end{array}$ & $\begin{array}{l}\text { Husks damage } \\
\text { (hd) }\end{array}$ & $\begin{array}{l}\text { Shank damage } \\
\text { (sd) }\end{array}$ & $\begin{array}{l}\text { MCB larvae per } \\
\text { plant (ml) }\end{array}$ & $\begin{array}{l}\text { ECB larvae per } \\
\text { plant (el) }\end{array}$ \\
\hline \multicolumn{8}{|c|}{ Natural infestation } \\
\hline 0 & 75.4 & 35.1 & 6.8 & 6.9 & 5.0 & 1.2 & 0.4 \\
\hline 6 & 72.7 & 30.1 & 6.8 & 7.0 & 5.0 & 0.9 & 0.5 \\
\hline 8 & 71.5 & 29.9 & 7.1 & 7.2 & 5.3 & 0.9 & 0.5 \\
\hline 10 & 70.8 & 28.6 & 7.1 & 7.2 & 4.9 & 0.7 & 0.4 \\
\hline \multirow[t]{2}{*}{12} & 68.5 & 28.1 & 7.2 & 7.3 & 5.0 & 0.7 & 0.4 \\
\hline & & $\mathrm{b}_{\text {tl.flif }}=1.02^{* *}$ & $b_{\text {kd.flif }}=-0.06^{* *}$ & $\mathrm{~b}_{\text {hd.flif }}=-0.06^{* *}$ & $\mathrm{~b}_{\text {sd.flif }}=-0.00 \mathrm{~ns}$ & $\mathrm{~b}_{\mathrm{ml.flif}}=0.08^{* *}$ & $\mathrm{~b}_{\text {el.flif }}=0.00 \mathrm{~ns}$ \\
\hline \multicolumn{8}{|c|}{ MCB infestation } \\
\hline 0 & 12.3 & 49.3 & 5.8 & 5.6 & 4.1 & 1.8 & \\
\hline 6 & 16.0 & 42.6 & 5.9 & 5.7 & 4.2 & 1.6 & \\
\hline
\end{tabular}




\begin{tabular}{|c|c|c|c|c|c|c|c|}
\hline 8 & 17.9 & 42.6 & 6.1 & 5.6 & 4.0 & 1.6 & \\
\hline 10 & 18.8 & 40.4 & 6.2 & 5.7 & 4.3 & 1.4 & \\
\hline \multirow[t]{2}{*}{12} & 19.5 & 39.9 & 6.4 & 5.7 & 4.1 & 1.5 & \\
\hline & & $\mathrm{b}_{\text {tl.flif }}=-1.26^{* * *}$ & $\mathrm{~b}_{\mathrm{kd} . \mathrm{flif}}=0.07 * *$ & $\mathrm{~b}_{\mathrm{hd} . f l i f}=0.01 \mathrm{~ns}$ & $\mathrm{~b}_{\text {sd.flif }}=0.01 \mathrm{~ns}$ & $b_{\text {ml.flif }}=-0.04 * * *$ & \\
\hline \multicolumn{8}{|c|}{ ECB infestation } \\
\hline 0 & -0.5 & 38.5 & 6.2 & 5.8 & 4.4 & & 1.2 \\
\hline 6 & 3.3 & 34.0 & 6.3 & 6.0 & 4.7 & & 1.1 \\
\hline 8 & 3.8 & 35.1 & 6.4 & 6.2 & 4.7 & & 1.1 \\
\hline 10 & 5.6 & 33.6 & 6.5 & 5.9 & 4.7 & & 1.1 \\
\hline \multirow[t]{2}{*}{12} & 6.2 & 32.5 & 6.6 & 6.3 & 5.2 & & 1.0 \\
\hline & & $b_{\text {tl.flif }}=-0.84^{* *}$ & $\mathrm{~b}_{\mathrm{kd} . f l i f}=0.05^{* *}$ & $\mathrm{~b}_{\text {hd.flif }}=0.05 \mathrm{~ns}$ & $\mathrm{~b}_{\text {sd.flif }}=0.09 *$ & & $b_{\text {el.flif }}=-0.02 * *$ \\
\hline
\end{tabular}


Table 2. Regression coefficients of tunnel length, kernel damage, husks damage, and shank damage on days to flowering

2 under natural infestation.

\begin{tabular}{|c|c|c|c|c|c|c|c|c|c|c|}
\hline & & \multicolumn{2}{|c|}{ Location } & \multicolumn{2}{|c|}{ Sowing date } & \multicolumn{3}{|c|}{ Level of inbreeding } & \multicolumn{2}{|c|}{ Population } \\
\hline & Total & Pontevedra & Zaragoza & Early & Late & × EP28 & S0 & S1 & Purdue A & Purdue B \\
\hline Tunnel & $0.248^{*}$ & 0.321 ns & $0.102 \mathrm{~ns}$ & $0.286 \mathrm{~ns}$ & $0.210 \mathrm{~ns}$ & $0.230 \mathrm{~ns}$ & $0.469^{* *}$ & $-0.006 \mathrm{~ns}$ & $0.168 \mathrm{~ns}$ & $0.349 \mathrm{~ns}$ \\
\hline \multicolumn{11}{|l|}{ length } \\
\hline Kernel & $-0.031^{* *}$ & $-0.018 \mathrm{~ns}$ & $-0.046^{* *}$ & $-0.061^{* *}$ & $-0.004 \mathrm{~ns}$ & $-0.041 \mathrm{~ns}$ & $-0.032^{* *}$ & $-0.017 \mathrm{~ns}$ & $-0.046^{* * *}$ & $-0.011 \mathrm{~ns}$ \\
\hline \multicolumn{11}{|l|}{ damage } \\
\hline Husks & $-0.018 \mathrm{~ns}$ & $-0.006 \mathrm{~ns}$ & $-0.041 \mathrm{~ns}$ & $-0.018 \mathrm{~ns}$ & $-0.019 \mathrm{~ns}$ & $-0.030 \mathrm{~ns}$ & $-0.037^{* *}$ & $0.012 \mathrm{~ns}$ & $-0.022 \mathrm{~ns}$ & $-0.014 n s$ \\
\hline \multicolumn{11}{|l|}{ damage } \\
\hline Shank & $0.031 \mathrm{~ns}$ & $0.040 \mathrm{~ns}$ & $0.008 \mathrm{~ns}$ & $0.001 \mathrm{~ns}$ & $0.061^{* *}$ & $-0.030 \mathrm{~ns}$ & $0.060^{* *}$ & $0.029 \mathrm{~ns}$ & $0.031 \mathrm{~ns}$ & $0.033 \mathrm{~ns}$ \\
\hline damage & & & & & & & & & & \\
\hline
\end{tabular}

3 ns, *,**, *** not significant and significant at $\mathrm{P}<0.10, \mathrm{P}<0.05$ and $\mathrm{P}<0.01$, respectively. 
2 from flowering to infestation under MCB infestation.

\begin{tabular}{|c|c|c|c|c|c|c|c|c|c|c|}
\hline & & \multicolumn{2}{|c|}{ Location } & \multicolumn{2}{|c|}{ Sowing date } & \multicolumn{3}{|c|}{ Level of inbreeding } & \multicolumn{2}{|c|}{ Population } \\
\hline & Total & Pontevedra & Zaragoza & Early & Late & $\times$ EP28 & S0 & S1 & Purdue A & Purdue B \\
\hline Tunnel & $-0.72^{* * *}$ & $-1.08^{* * *}$ & $-0.20 \mathrm{~ns}$ & $-0.57^{* * *}$ & $-0.91^{* * *}$ & $-0.34 \mathrm{~ns}$ & $-0.68^{* *}$ & $-0.98^{* * *}$ & $-0.20 \mathrm{~ns}$ & $-1.28^{* * *}$ \\
\hline \multicolumn{11}{|l|}{ length } \\
\hline Kernel & $0.087^{* * *}$ & $0.057^{* * *}$ & $0.126^{* * *}$ & $0.144^{* * *}$ & $0.020 \mathrm{~ns}$ & $0.081^{* * *}$ & $0.079^{* * *}$ & $0.098^{* * *}$ & $0.121^{* * *}$ & $0.048^{* *}$ \\
\hline \multicolumn{11}{|l|}{ damage } \\
\hline Husks & $0.015 \mathrm{~ns}$ & $0.019 \mathrm{~ns}$ & $0.010 \mathrm{~ns}$ & $0.018 \mathrm{~ns}$ & $0.011 \mathrm{~ns}$ & $-0.009 \mathrm{~ns}$ & $0.029 \mathrm{~ns}$ & $0.015 \mathrm{~ns}$ & $0.028 \mathrm{~ns}$ & $0.000 \mathrm{~ns}$ \\
\hline \multicolumn{11}{|l|}{ damage } \\
\hline Shank & $0.006 \mathrm{~ns}$ & $0.011 \mathrm{~ns}$ & $0.001 \mathrm{~ns}$ & $0.051 \mathrm{~ns}$ & $-0.046 n s$ & $0.051 \mathrm{~ns}$ & $0.003 \mathrm{~ns}$ & $-0.017 \mathrm{~ns}$ & $0.021 \mathrm{~ns}$ & $-0.011 \mathrm{~ns}$ \\
\hline damage & & & & & & & & & & \\
\hline
\end{tabular}

3 ns, *, **, *** not significant and significant at $\mathrm{P}<0.10, \mathrm{P}<0.05$ and $\mathrm{P}<0.01$, respectively. 
2 from flowering to infestation under ECB infestation.

\begin{tabular}{|c|c|c|c|c|c|c|c|c|c|c|}
\hline & & \multicolumn{2}{|c|}{ Location } & \multicolumn{2}{|c|}{ Sowing date } & \multicolumn{3}{|c|}{ Level of inbreeding } & \multicolumn{2}{|c|}{ Population } \\
\hline & Total & Pontevedra & Zaragoza & Early & Late & $\times$ EP28 & S0 & S1 & Purdue A & Purdue B \\
\hline Tunnel & $-0.15 n s$ & $-0.15 n s$ & $-0.16 \mathrm{~ns}$ & $-0.63^{* *}$ & $0.30 \mathrm{~ns}$ & $0.05 \mathrm{~ns}$ & -0.33 ns & $-0.10 n s$ & -0.52 ns & $0.25 \mathrm{~ns}$ \\
\hline \multicolumn{11}{|l|}{ length } \\
\hline Kernel & $0.02 \mathrm{~ns}$ & $0.01 \mathrm{~ns}$ & $0.05^{* *}$ & $0.06^{* *}$ & $-0.01 \mathrm{~ns}$ & $0.06^{* *}$ & $0.02 \mathrm{~ns}$ & $-0.01 \mathrm{~ns}$ & $0.05^{* *}$ & $-0.01 \mathrm{~ns}$ \\
\hline \multicolumn{11}{|l|}{ damage } \\
\hline Husks & $0.03^{*}$ & $0.03 \mathrm{~ns}$ & $0.04 \mathrm{~ns}$ & $0.08^{* * *}$ & $-0.02 \mathrm{~ns}$ & 0.02 ns & $0.07^{* *}$ & $-0.02 n s$ & 0.03 ns & $0.03 \mathrm{~ns}$ \\
\hline \multicolumn{11}{|l|}{ damage } \\
\hline Shank & $-0.00 n s$ & $-0.08^{*}$ & $0.12^{* * *}$ & $0.02 \mathrm{~ns}$ & $-0.02 \mathrm{~ns}$ & $0.08 \mathrm{~ns}$ & $-0.00 \mathrm{~ns}$ & $-0.08 n s$ & $0.01 \mathrm{~ns}$ & -0.02 ns \\
\hline damage & & & & & & & & & & \\
\hline
\end{tabular}

$3 \mathrm{~ns}, *, * *, * * *$ not significant and significant at $\mathrm{P}<0.10, \mathrm{P}<0.05$ and $\mathrm{P}<0.01$, respectively. 